\title{
ECOLOGICAL ROAD PLANNING IN NORTHERN SASKATCHEWAN
}

\section{A Study of Alternative Routes for the Proposed Road from Besnard Lake to Sandfly Lake, Sask.}

\author{
by JONATHAN M. GERRARD and P. NAOMI GERRARD*
}

\begin{abstract}
In this report we use data on Bald Eagle nesting and feeding habitat presented in ther article in this issue to suggest how roads in northern Saskatchewan might be nned to minimize effects on Bald Eagles. The study reported here has already been mitted to the Honourable Ted Bowerman, Minister of the Department of Northern katchewan, and the final decision on the route of this road currently hangs in the ance. We present this study here to show how our earlier research can be used to planning and development in northern Saskatchewan, and to generate support $n$ the members of the Saskatchewan Natural History Society for a change in the posed location of this road and a change in the present policy of planning roads in thern Saskatchewan.
\end{abstract}

Research during the last 8 years has wn that Saskatchewan has a large eding population of Bald Eagles. ${ }^{4} 7$ $W$ ith the decline in numbers of this ecies in many parts of North herica, ${ }^{2} 5141516$ northern Saskatwan with a mid-summer population about 12,000 Bald Eagles is now of the major remaining breeding ervoirs, and is a major source for les wintering in the midwestern ited States." The continued stence of large numbers of these big hutiful birds in northern Saskatwan depends on preservation of ir nesting habitat and the continued ilability of fish for them to eat.

furrently, the economy of northern katchewan is in transition from one hunting, fishing and trapping to a re diversified one in which pulpting, mining and recreation are

15th Ave. S.E.,

inneapolis, Minn. 55414 playing important roles. New roads are now providing easy access to areas which heretofore had been accessible only to travellers by canoe or bush plane. These roads are the arteries along which future development will take place. Presently, many of these roads are designed and built by the Prince Albert Pulp Company to reach areas of harvestable stands of timber. The routes for these roads are usually the shortest alternative between two points with a view to minimizing trucking costs which are estimated at a fixed rate per mile. In view of the many other features of northern Saskatchewan which are worthy of consideration, in particular Bald Eagles, we reviewed the location of a segment of a proposed road running north from Besnard Lake towards Sandfly Lake (Fig. 1). Emphasis was placed on habitat requirements for Bald Eagles. In addition, ecological features which will be important to the future fishing, hunting and 
recreational potential of northern Saskatchewan were considered. To obtain a balanced view of the alternative routes for the road, landscape features which play a role in the cost of construction and maintenance of a highway were also identified along with forests suitable for pulp harvest.

METHODS. The method employed in planning the optimum route was that of McHarg. ${ }^{12}$ Briefly, each of the factors to be considered was graded on a scale of one to three. A map was then drawn with optimum areas for the road (grade 1) left transparent, suboptimum but acceptable areas for the road (grade 2) coloured grey, and poor areas for the road (grade 3) coloured black. Each factor (soil, slope, etc.) was analyzed separately, and the maps for each factor were then superimposed so that the optimum position for the road could be visualized as the place where the lightest coloured areas were located.

RESULTS. Optimum terrain for road construction: Two factors relating to optimum terrain for road construction are soil conditions and the slope of the land.

The optimum soil conditions for road construction in this area are sandy and gravelly soils (Fig. 2), because gravel is required for a road bed and it is easier and less costly to build a road on a sand or gravel base than on a rock base. Specific information on soil types in this area is lacking, but it is known that Jack Pines tend to grow in areas with sandy and gravelly soils. Thus areas where there were Jack Pines were considered to have optimum soil conditions (grade 1). Marshes and lakes were considered poor conditions for roads (grade 3 ). All other areas were considered grade 2. Information of the location of Jack Pine stands and the areas where there were lakes and marshes was obtained from inventory maintenance mar (Dept. of Natural Resources, Sask An example of current soil erosic may be seen in Fig. 7 .

Steep slopes (greater than 10\% were considered poor places for roa construction (grade 3 ). ${ }^{12}$ More gent slopes $(2.5-10 \%)$ were considered it termediate (grade 2). Flat land (slop less than $2.5 \%$ ) were considered of timum for road construction an graded 1. Information on slopes $w$ obtained from a 1:50,000 map (Su veys and Mapping Branch, Dep Energy, Mines and Resources, Ottav 1973 ) with contour intervals of $25 \mathrm{fe}$ (Fig. 3).

Optimum Route for Harvesting Fores for Pulp: Mature forests where tre were greater than 50 feet in heig were considered optimum for ha vesting for pulp (grade 1). Areas whe trees were 30 to 50 feet in height we classified as intermediate (grade and areas where trees were less than feet in height were considered grade (Fig. 4). The presence of softwood hardwood in the stands was not tak into consideration because dete mination of the optimum soil co ditions had already created a bi towards softwoods, and future ho vesting for pulp will include har woods as well as softwoods. Tree de sity was not taken into account, exce that sparsely treed areas such as ro ridges were classified grade 3 , becau this complicated the analysis witho altering the map significantly.

Optimum route to Minimize Effects Wildlife: In the preparation of this $m$ (Fig. 5) the following areas were cc sidered: 1) the marshes with t nearby forest edge and associat streams and ravines which are the mi productive habitat for wildlife - $t$ ducks, moose and fur bearing anim - important to local trappers a hunters: 2) spawning grounds for fi and 3 ) nesting and feeding areas 

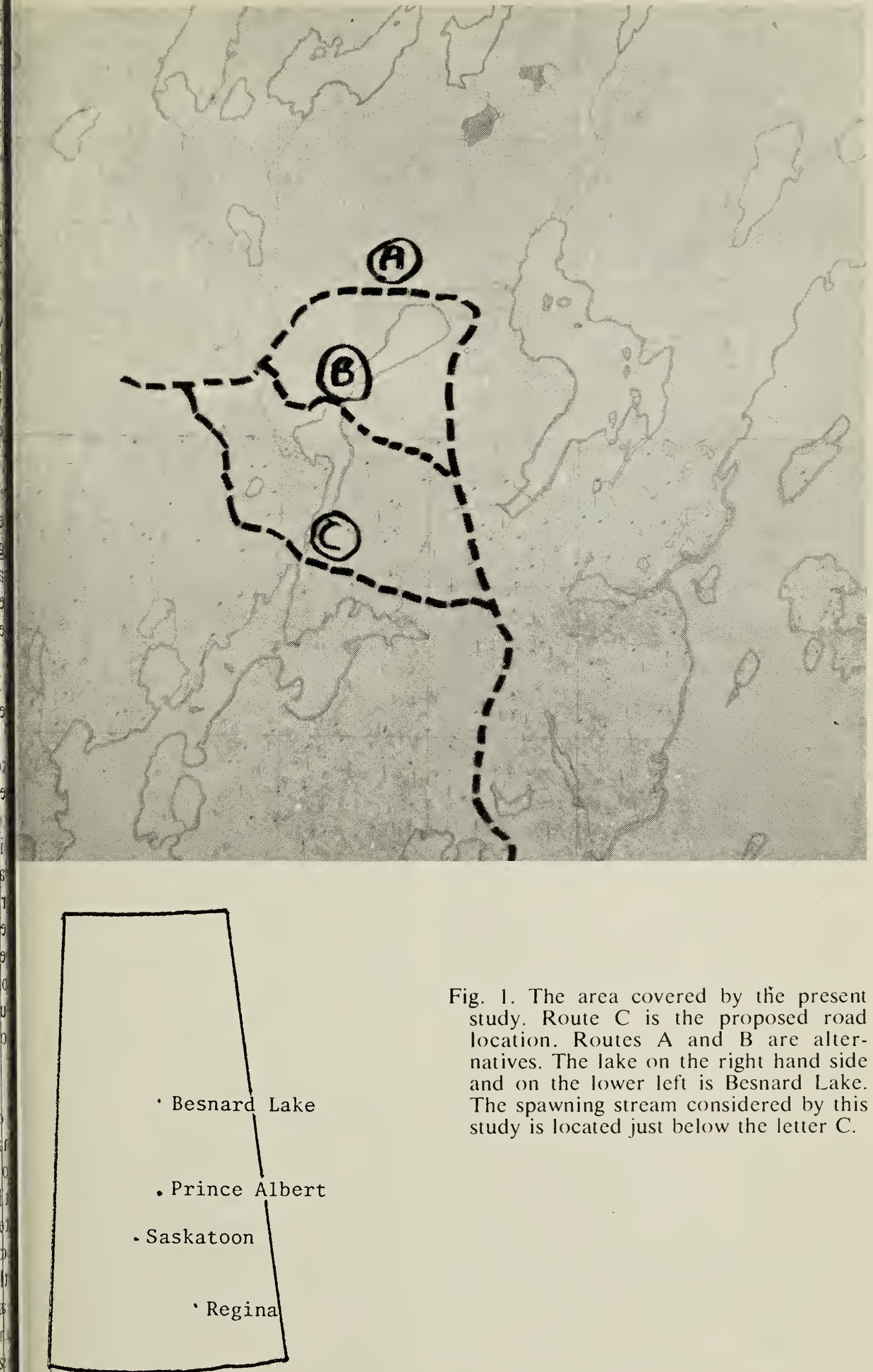

Saskatchewan

Fig. 1. The area covered by the present study. Route $C$ is the proposed road location. Routes $A$ and $B$ are alternatives. The lake on the right hand side and on the lower left is Besnard Lake. The spawning stream considered by this study is located just below the letter C. 
Bald Eagles. The marshes are classed as poor locations for roads in Fig. 2, and were not again marked on the map shown in Fig. 5. John Hastings, manager of Red's Camp and a long time resident of Besnard Lake, was asked to mark important spawning streams flowing into the lake. The only spawning area in the region considered by the present study is at the entry of a small stream into Besnard Lake (Figs. 1 and 8). Walleye and Northern Pike can be seen spawning in large numbers each spring near this stream and in the adjacent bay. The importance of Besnard Lake for fishing (both commercial and sport) and the importance of this spawning area as a source of food for Bald Eagles on their arrival at Besnard Lake in the early spring, led us to suggest a buffer zone (a circle $1 / 2$ mile in diameter) as a poor place to put a road (grade 3 ) and an additional zone, $1 / 2$ mile in width, which would be intermediate in terms of the route (grade 2). Eagle nests were given a buffer zone ( $1 / 4$ miles in diameter grade 3) where definite adverse effects of a road would be expected and an additional zone $1 / 4$ mile wide was considered grade 2 where less severe adverse effects might occur. These figures are taken from a study by Greg Jeunemann done in northern Minnesota on the Chippewa National Forest." They represent the best available figures on the effects of human disturbance on Bald Eagles. We suggest that, if anything, these zones may be too small for northern Saskatchewan, though more research will be needed to substantiate this belief. We have already shown that the most critical time for disturbance near eagle nests in Saskatchewan is from March 20 to July 1 during courtship, incubation and when the young are small, and it may be that a larger buffer zone for this time interval alone will suffice."

Since about $12 \%$ of Bald Eagles in northern Saskatchewan change ne sites each year, we also considere habitat suitable for Bald Eagle nestir but which currently has no nest site Using quantitative data on th utilization of shoreline habitat in th area by Bald Eagles, ${ }^{\star}$ we coloure black all zones where these bir could be expected to have one or mo nests per $1 / 4 \mathrm{sq} \mathrm{mi}$, and we colour grey all habitat where Bald Eagl could be expected to have one or mo nests per sq mi.

A Composite Map: A consideration possible routes for the road goil north from Besnard Lake towar Sandfly Lake yields three alternativ for the segment studied in this repo (Fig. 1). Superimposition of the ma shown in Figs. 2-5 gives a combin map in which areas are graded one five in degrees of darkness (Fig. 6). ( the composite map the areas m. suited for the road are lightest, and $t$ areas least suited are the darkest. T route which is most consistently lig is route $A$ from Fig. 1, and this labelled first choice (1) on Fig. 6. T route which appears to offer $t$ second best alternative is route $B$, at this is labelled second choice (2) Fig. 6. Route B needs to be seriou: considered since it is somewhat shor than route $A$. However, there is a ste slope along route $B$ which would al make construction more difficult.

From the composite map it can seen that route $\mathrm{C}$ is the poorest cho of all. This route would necessit putting the road through three areas steep slope. It might be possible avoid one or two of these areas of ste slope but at a cost of putting the ro through marshes. Furthermore $t$ route goes through a small stre where fish spawn in the spring, an a that is an important spring feed ground for Bald Eagles. In view of importance of this area to eagles, a to future fishing, hunting and trappi 
e feel that the road should not go ear this small stream if there is any ther possible location. The present udy shows that routes $A$ and $B$ are oth possible alternatives, and that hey are both feasible and indeed uperior to route $\mathrm{C}$ when looked at om several aspects. In view of these ndings, we strongly urge that the resent plans which would put the pad through on route $C$ be altered ind instead either route $A$ or route $B$ chosen.

ISCUSSION. The present investigation is studied a segment of a proposed bad from Besnard Lake to Sandfly ake placing particular emphasis on le habitat requirements of Bald agles. The dependence of these igles on shoreline habitat which is the me habitat most frequently chosen people for cottages makes these rds uniquely susceptible to the inuence of human development. A view of the decrease in numbers of ald Eagles in other parts of North merica suggests that human disturbice and habitat destruction are ajor factors. ${ }^{1}$; $; 1416$ On Manhattan land in New York in the 1800's, eorge Grinnel recalled that the Bald agle was "extremely abundant on the rating ice of the river and sometimes ought its captive fish to the trees in e park, there to eat them or as often quarrel about them with its fellow, id sometimes drop the prey." Alas, is sight is now only a memory. oberts in The Birds of Minnesota entions that there used to be one or ore pairs nesting on nearly every rge lake in the state. ${ }^{13}$ Presently Bald agles breed commonly in only a few irts of northern Minnesota. Today in iskatchewan there are one or more iirs of eagles nesting on nearly every asonably sized lake in northern iskatchewan from the Cumberland arshes in the southeast to Lake thabaska in the northwest. Larger lakes like Besnard Lake have many more. Concern for the future of these eagles prompted the present study.

In this report, we emphasize the fact that, in the rush to build roads for harvesting pulp, important aspects of the northern environment are not receiving adequate attention. We prepared this study not just to look at alternatives to a short segment of proposed road, but also to serve as an example of how various factors in the northern Saskatchewan environment, particularly eagles, can and should be considered in the building of roads. We recognize that there are defects in the present study. Due to lack of information, the depth of bedrock, an important consideration for northern road building, was not taken into account. Jack Pines can grow on well drained areas where there is exposed bedrock as well as on sandy and gravelly soils. In such areas, Jack Pines are usually sparse and short. We feel that through consideration of tree height and classification of sparsely treed areas as grade 3 in Fig. 3, most such areas have been included in the darker areas on the composite map.

In spite of these defects, we feel this study has served a useful purpose in integrating several environmental factors and future human activities into plans for road building in the north. It was instructive to us to realize that the optimum place for road construction and harvesting pulp — well drained areas with climax forest - are usually poor places for wildlife, while the most productive areas for wildlife marshes with the nearby forest edge and the associated streams and ravines - are usually poor places for road building and pulp cutting. With careful planning it should, therefore, be possible to have considerable pulp cutting in the north and still minimize the adverse effects on wildlife. Without such planning, it is likely that many important aspects of our nor- 


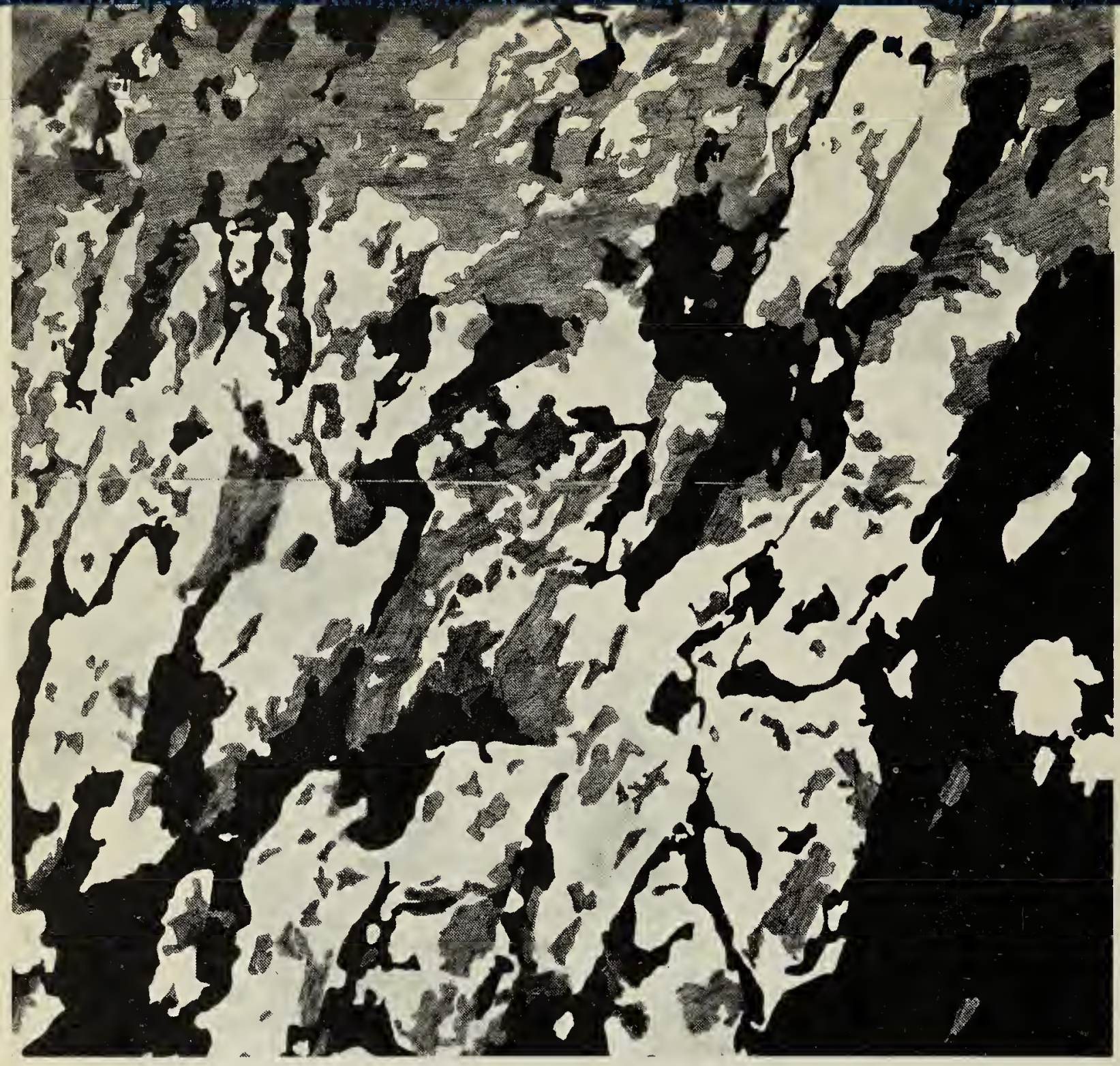

Fig. 2.

Analysis

of soil

conditions.

Optimal

conditions

for the

road are

white,

suboptimal conditions for the

road are grey and poor conditions for the road are black.

Fig. 3 .

Slope of the land. Areas of steep slope are black, moderate slope grey and flat land is white.

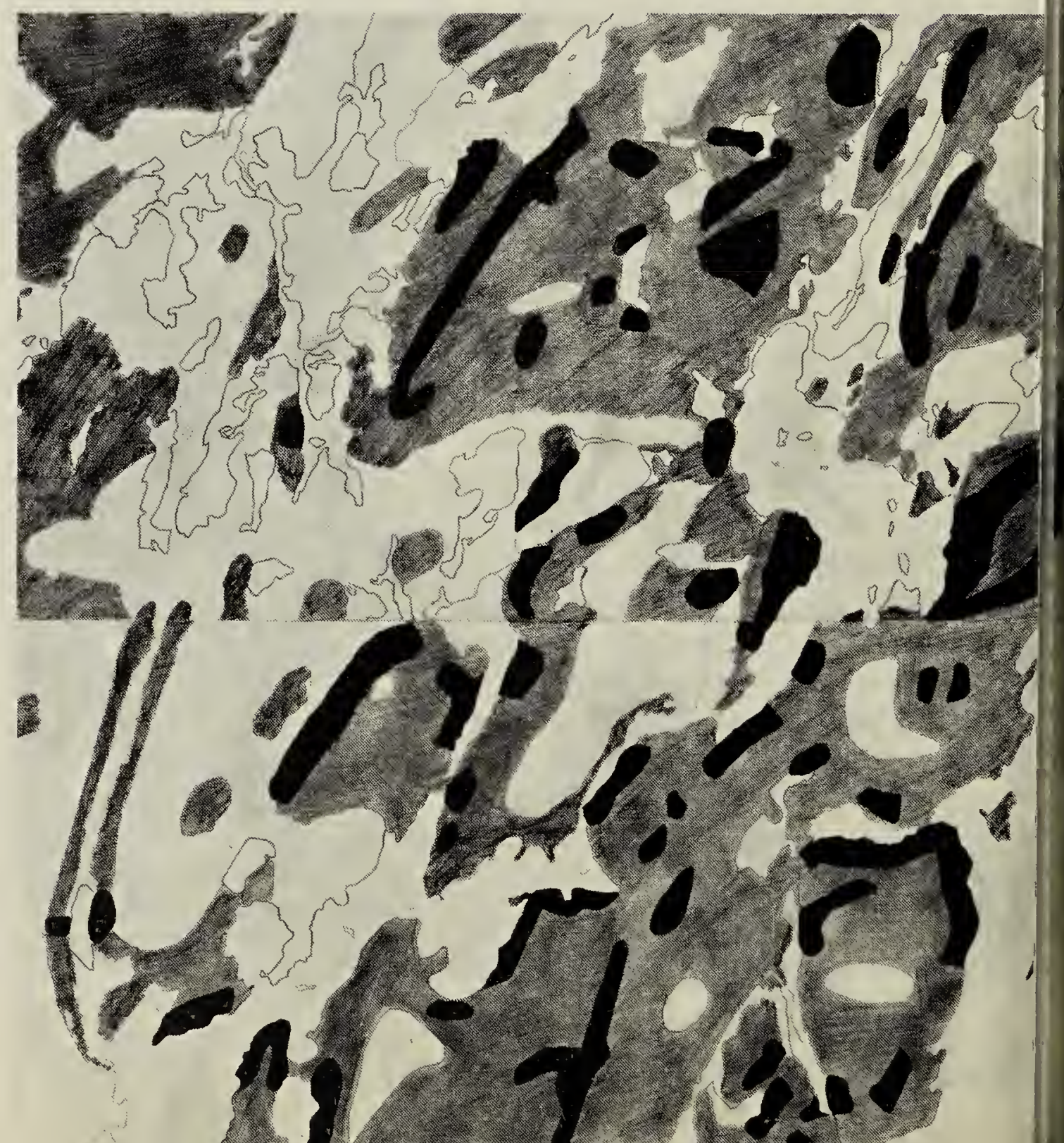




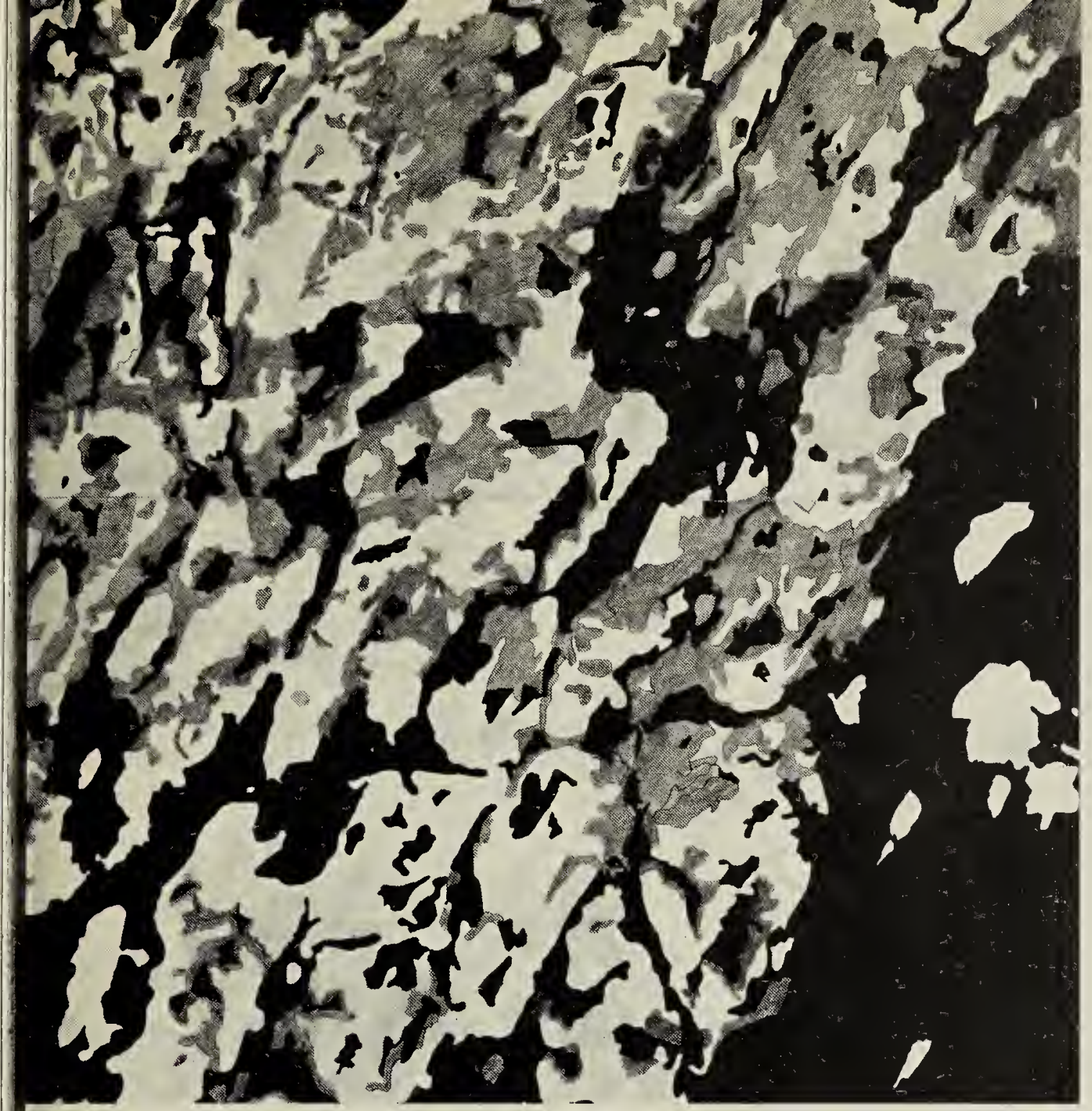

Fig. 4.

Suitability

of forests

for harvest

for pulp.

Optimum

forests for

pulp are

white,

suboptimum

grey, and

poor forests

are black.

ig. 5

reas

mportant

wildlife.

lack areas

epresent

agle nest

ites, fish

oawning

reas or

ptimum

agle nesting

abitat.

irey areas

re buffer

ones for

he above,

$\mathrm{r}$

uboptimal

agle nesting

abitat.

White areas

re poor

pald Eagle

esting

abitat.
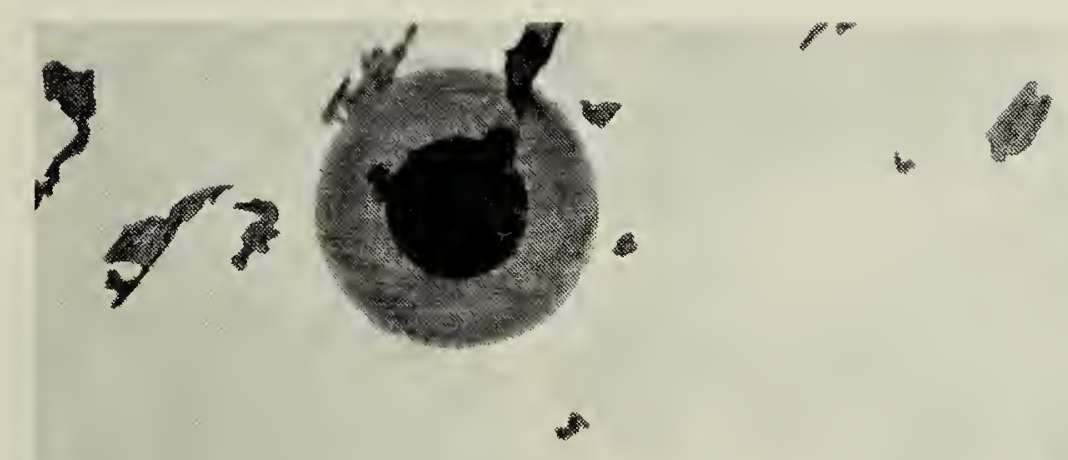

4

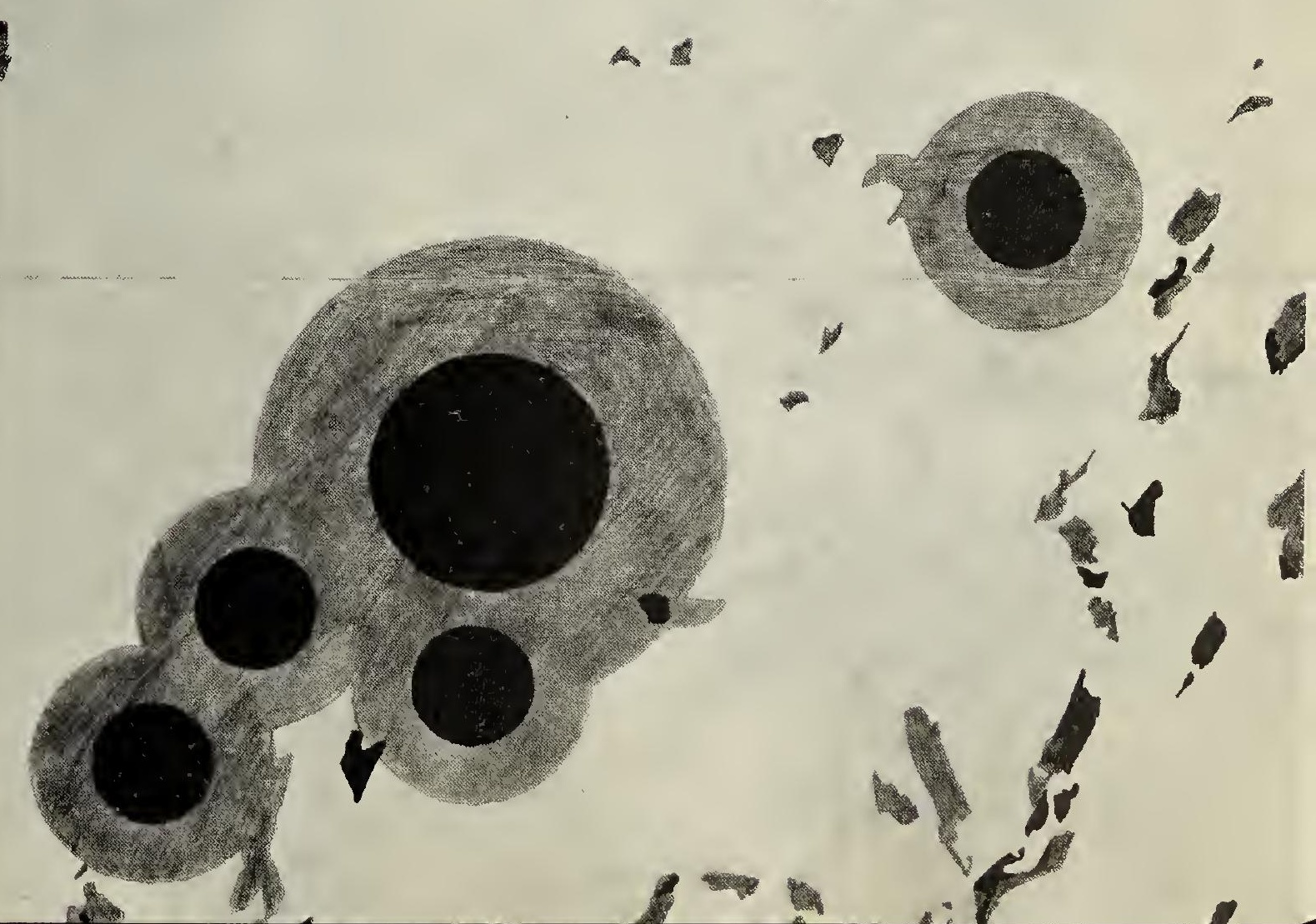




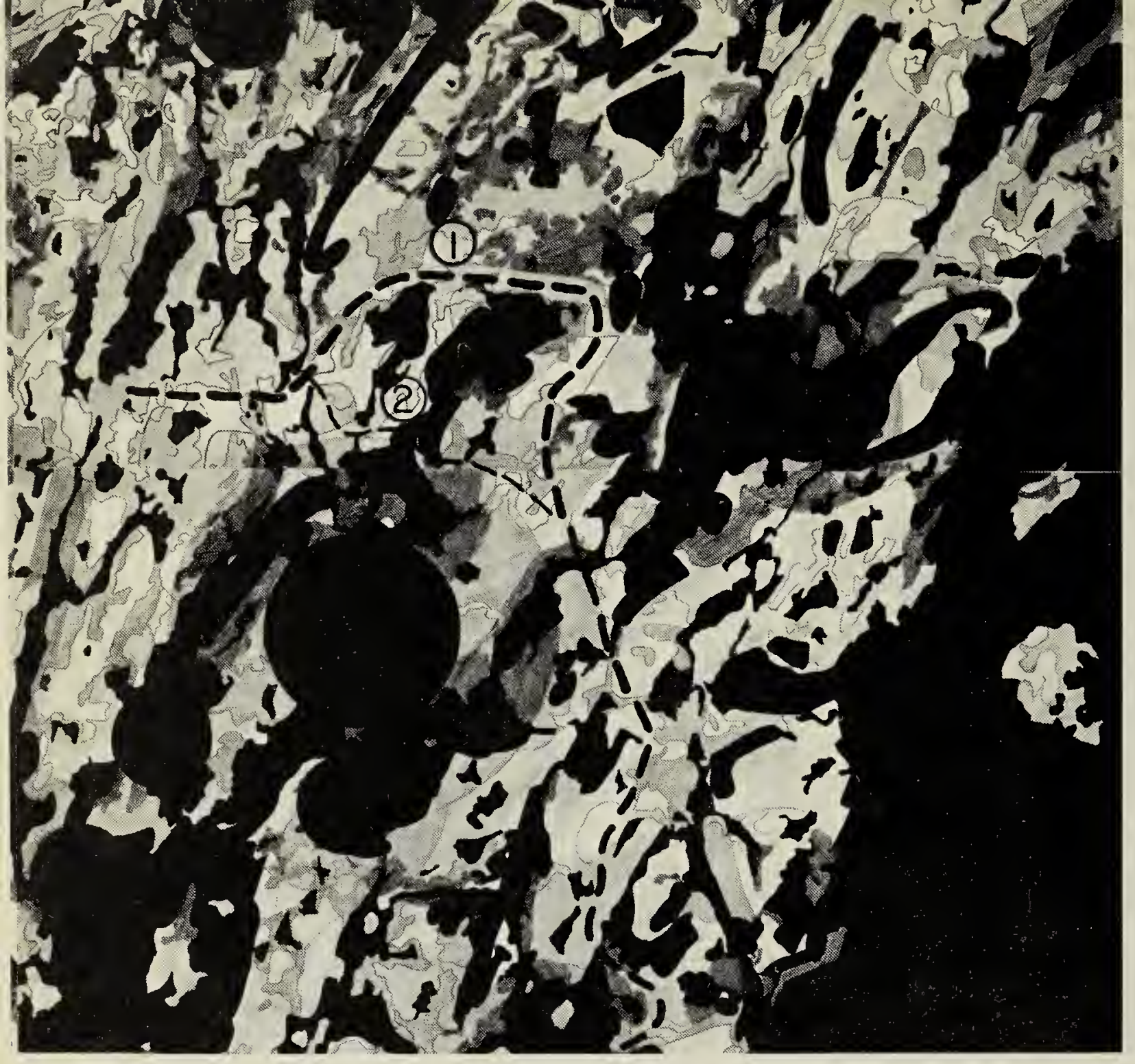

Fig. 6.

The

Composi map: The alternativ labelled (1) is the best over route.

Alternati (2) is the second $b$

Fig. 7. Erosion along the present road to Besnard Lake is particularly severe where the road crosses the Montreal River. As a result of this erosion the Montreal River in spring changes from a clear stream above the road to a brown turbid stream below it. Such increased turbidity in a spawning area during the critical time of spring runoff may have a drastic effect on spawning fish.

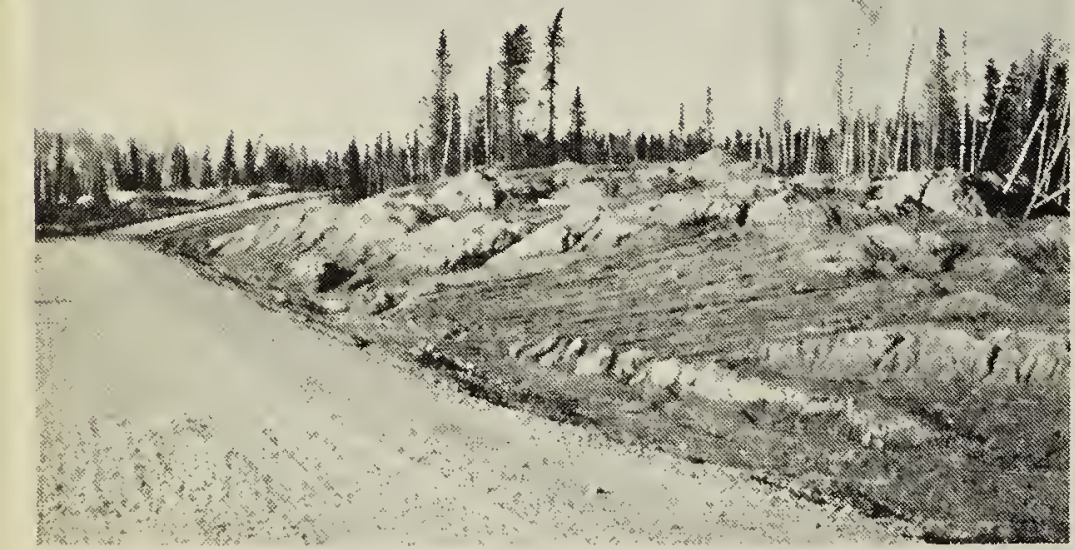

Fig. 8. The small stream referred to in present study where fish spawn e spring. This photograph was taken early April, 1975, 5 to 7 weeks before ice is usually gone from the main bod the lake. Already the flow in this stro has resulted in some open water.

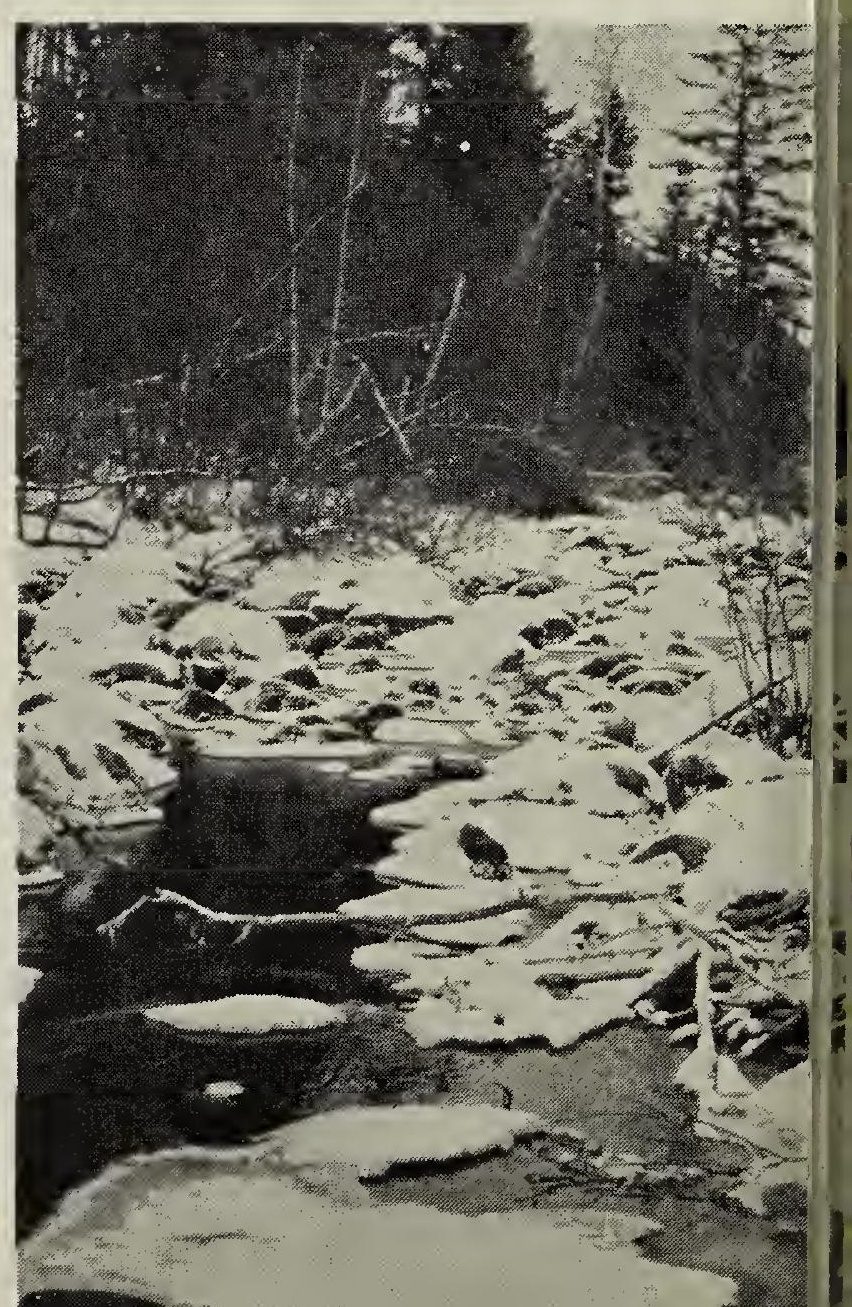


ern Saskatchewan heritage will be st.

JMMARY. Studies were conducted on ternate routes for a segment of the ad planned from Besnard Lake to indfly Lake. These studies take into count 1) the most suitable terrain o a road, 2) the location of forests ith trees which are suitable for harest for pulp and 3 ) the location of hportant areas for wildlife. The study ggests two alternative routes for the ad, either of which would be more nitable than the presently proposed pute and serves as an example of how lanning for roads and other developent in northern Saskatchewan might ke into account the habitat quirements of Bald Eagles and other ildlife.

CKNOWLEDGEMENTS: The helpful omments and suggestions of W. J. laher, D. W. A. Whitfield, J. F. Daly, Morrison, G. Roberts and A. Piper e appreciated.

RROLEY, C. L. 1950. The plight of the Florida Bald Eagle. Audubon Mag. 52:43.

ROLEY, M. J. 1952. Eagle man. Pellegrini and Cudahy, New York. 186 p.

JUNNINGHAM, R. L. 1960. The status of the Bald Eagle in Florida. Audubon Mag. 62:24.

sERRARD, J. M., and D. W. A. WHITFIELD. Bald Eagle banding in norihern Saskatcliewan. Blue Jay 25:177.

BERRARD, J. M. 1973. The Bald Eagles in Canada's nortlern forests. Nature Canada 2:10.

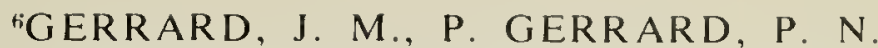
GERRARD, D. W. A. WHITFIELD and W. J. MAHER. 1973. Bald Eagle belavior study Part II. Final report to Canadian Wildlife Service on contract CWS-7273-43.90 p. (mimeo).

${ }^{i}$ GERRARD, J. M., P. GERRARD, F. A. LEIGHTON, W. J. MAHER and D. W. A. WHITFIELD. 1975. A census of ile Bald Eagles of Saskatchewan. Unpublished report to the Churchill River Wildlife Study Sector.

${ }^{*}$ GERRARD, J. M., P. GERRARD, W. J. MAHER and D. W. A. WHITFIELD. 1975. Habitat and nest site selection of Bald Eagles in northern Saskatchewan and Manitoba. Blue Jay 32 (this issue).

"GERRARD, P., J. M. GERRARD, D. W. A. WHITFIELD and W. J. MAHER. 1974. Postfledging movements of juvenile Bald Eagles. Blue Jay 32:218.

"'GRINNEL, G. B. 1920. Recollections of Audubon Purk. Auk 37:372.

"JUENEMANN, B. G. 1973. Habitat evaluation of selected Bald Eagle nest sites on the Clippewa National Forest. M.Sc. Thesis, University of Minnesota, Minneapolis.

1.McHARG, I. L. 1969. Design with nature. Doubleday and Co. Inc., Garden City, New York.

${ }^{13}$ ROBERTS, T. S. 1932. The birls of Minnesola. The University of Minnesota Press, Minneapolis.

"SPRUNT, A. IV, 1969. Population trneds of the Bald Eagle in Nortl America. In Peregrine Falcon Populations. Ed. J. J. Hickey. Univ. Wisconsin Press, Madison.

".sPRUNT, A. IV., W. B. ROBERTSON Jr., S. POSTUPALSKY, R. J. HENSEL, C. E. KNODER and F. J. LIGAS. 1973. Comparative Productivity of six Bald Eagle populations. Trans. N.A. Wildl. Nat. Res. Conf. 38:96.

16WEEKES, F. 1973. A survey of Bald Eagle nesting atternpts in southern Ontario, 1969-1973. Can. Field-Nat. 88:415.

${ }^{17}$ WHITFIELD, D. W. A., J. M. GERRARD, D. W. DAVIS and W. J. MAHER. 1974. Bald Eagle nesting habitat, density, and reproduction in central Saskatclewan and Manitoba. Can. FieldNat. 88:399.

The largest number of Bald Eagles recorded in the 1974 Christmas Bird Census or North America was at Klukwan, Alaska $\left(59^{\circ} \times 135^{\circ}\right)$. In the standard 6-sq-mi count area, 1162 eagles were found. 